\title{
Magnetometric Characterization of the Rio do Peixe Basin, Brazil
}

\author{
Kaio da Silva Pimentel Figueiredoㅁ, Gabriel Machado Stutz Xavier ${ }^{1}$, Dayane de Souza Pereira" \\ Jennifer Santos Rosaㄹ, Tainá de Mello Ribeiro² ${ }^{2}$, Hans Schmidt Santos ${ }^{1}$, \\ Felipe Barbosa Venâncio de Freitas ${ }^{3}$, Rogério Manhães Soares' ${ }^{1}$, Rayssa Barcellos Paiva1
}

${ }^{1}$ Production Engineering College, Faculdade Salesiana Maria Auxiliadora, Macaé, Brasil

${ }^{2}$ Chemical Engineering College, Faculdade Salesiana Maria Auxiliadora, Macaé, Brasil

${ }^{3}$ Universidade Federal do Rio de Janeiro, UFRJ, Rio de Janeiro, Brazil

Email: kaio_figueiredo@yahoo.com.br, gabriel.msx@hotmail.com, dayanepereira05@outlook.com, rogeriomanhaes5@gmail.com, rayssabpaiva@hotmail.com, hans.schmidt@live.com, felipebvenancio@gmail.com, jennifer23rosa@gmail.com, tatademelloribeiro@hotmail.com

How to cite this paper: da Silva Pimentel Figueiredo, K., Xavier, G.M.S., de Souza Pereira, D., Rosa, J.S., de Mello Ribeiro, T., Santos, H.S., de Freitas, F.B.V., Soares, R.M. and Paiva, R.B. (2019) Magnetometric Characterization of the Rio do Peixe Basin, Brazil. Open Access Library Journal, 6: e5362.

https://doi.org/10.4236/oalib.1105362

Received: March 30, 2019

Accepted: April 26, 2019

Published: April 29, 2019

Copyright $\odot 2019$ by author(s) and Open Access Library Inc.

This work is licensed under the Creative Commons Attribution International License (CC BY 4.0).

http://creativecommons.org/licenses/by/4.0/

\begin{abstract}
This work presents the analysis of magnetometric data of an aerial survey conducted in the Rio do Peixe Sedimentary Basin, which is a promising oil producing region in the state of Paraiba, Brazil. The collected aeromagnetometric data allowed the preparation of maps regarding magnetic anomaly, horizontal and vertical derivatives, analytical signal and Euler Deconvolution that were compared with the geology, topography, and regional seismic. Thus, we identified the main lineaments of the basin that were Tatajuba, Portalegre, and Malta faults. Furthermore, we also found a maximum basin depth of almost $1400 \mathrm{~m}$, which is compatible with the available seismic survey.
\end{abstract}

\section{Subject Areas \\ Environmental Sciences, Geology, Geomorphology, Geophysics}

\section{Keywords}

Magnetometry, Rio do Peixe Basin, Euler Deconvolution

\section{Introduction}

Magnetic surveying has a wide range of applications, from small scale engineering or archaeological surveys to detect buried metal objects, as well as large-scale surveys to investigate regional geological structures. These surveys can be carried out on land, sea, and air. Currently, aeromagnetic methods have been widely 
used as a rapid way of estimating the depth of structures from magnetic field data [1].

Magnetic prospecting in the petroleum area aims to measure small variations in the intensity of the earth's magnetic field, as a consequence of the irregular distribution of magnetized rocks. In a magnetic survey, it is possible to investigate Earth's geology based on its magnetic field anomalies resulting from the magnetic properties of the subsurface rocks. Since it is known that a potential accumulation of hydrocarbons occurs in sedimentary rocks that have a very low magnetic susceptibility [2].

The Rio do Peixe Basin is located almost entirely in Paraíba state, with a small portion to the west of Ceará state. It occupies an area of $1424 \mathrm{~km}^{2}$ with an elliptical shape elongated to ESE-WNW, divided into three sub-basins: Brejo das Freiras or Triunfo, Sousa and Pombal. It belongs to the set of northern smaller inland basins of Brazil-Vale do Cariri (Araripe, Iguatú, Lavras da Mangabeira, Icó) [3].

The expectation of exploration and production of hydrocarbons motivated PETROBRAS to promote several geophysical surveys in the region, so that, today it is entirely covered by aeromagnetic surveys such as those provided by the National Agency of Petroleum, Natural Gas and Biofuels (ANP) and are used in this work.

In this work, the Iguatu Project's aerogeophysical data are used, covering the entire study area. Through the processing of these data, the main magnetic bodies of the region were located, then being correlated with local geology and tectonics, allowing the estimation of the basin depth with the application of the Euler Deconvolution technique.

The paper was organized as follows: Section 2 presents the description, geology, tectonics, formation (Antenor Navarro, Sousa, and Rio Piranhas), topography, and geological map of the Rio do Peixe basin; Section 3 discusses the magnetometric method; in Section 4 the processing and interpretation of the generated maps are presented; finally, Section 5 presents the main conclusions of this work.

\section{The Rio do Peixe Basin}

\subsection{Location of the Rio do Peixe Basin}

The Rio do Peixe Basin is located at the NW boundary of Paraíba (PB) with Ceará (CE) states (Figure 1), encompassing the municipalities of Sousa, Uiraúna, Poço, Brejo das Freiras, Triunfo, Santa Helena and Pombal, more precisely between the meridians $37^{\circ} 47^{\prime} 00^{\prime \prime}$ and $38^{\circ} 50^{\prime} 00^{\prime \prime}$ west longitude, and between the parallels $06^{\circ} 25^{\prime} 00^{\prime \prime}$ and $06^{\circ} 50^{\prime} 00^{\prime \prime}$ south latitude [4].

Access to this area is done through federal highways, BR-230 (leaving from Pombal to Sousa), and by BR-405 (leaving from Cajazeiras to Uiraúna), or even on state highways, via PB-393, leaving Marizópolis for São João do Rio do Peixe and PB-391 connecting the city of Sousa to Uiraúna [4]. 


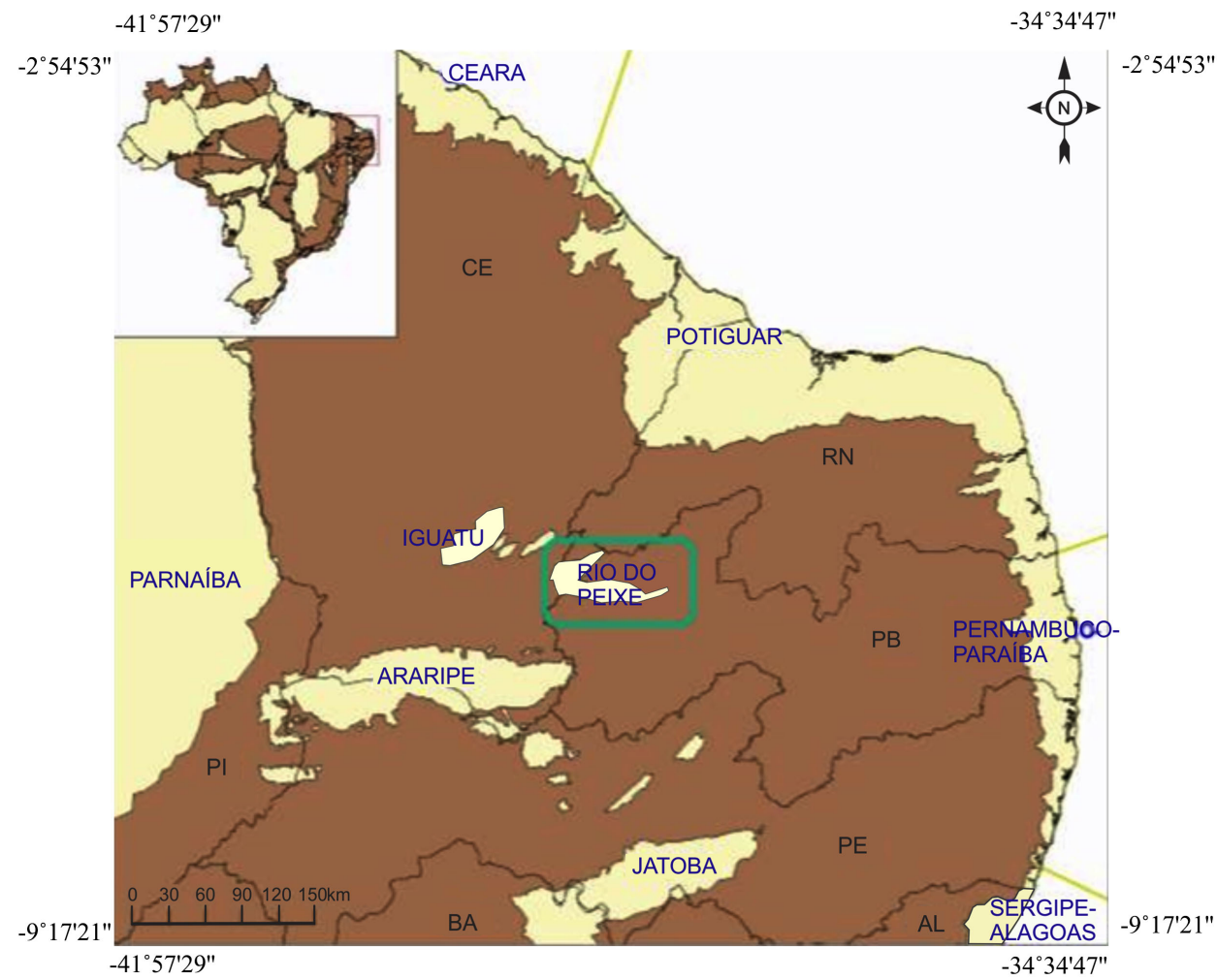

Figure 1. Location of the Rio do Peixe Basin [3].

\subsection{Geology}

The Rio do Peixe Sedimentary Basin is one of the main Cretaceous basins of the northeast of Brazil, containing important paleontological sites. It is located in a set of Mesozoic basins where there are productive areas and good indicators of the existence of petroleum [5].

More detailed geological surveys of the Rio do Peixe Basin have been carried out in recent years. Geochemical data, in addition to the occurrence of oil exudates indicate good conditions for possible accumulation of hydrocarbons, highlighting the need to consider this and other similar basins in the scenario of exploration activities in the Northeast of Brazil [3].

According to Silva (2009) [6], the basin is divided into three sub-basins that correspond to the semi-grabens of Triunfo or Brejo das Freiras, Sousa and Pombal, being crossed by three major faults Tatajuba Fault, Portalegre Fault and Malta Fault (Figure 2 and Figure 3).

Figure 4 presents $\mathrm{A}$ and $\mathrm{B}$ sections shown in Figure 3. The Rio do Peixe Group is composed by Antenor Navarro (lower), Sousa (intermediate) and Rio Piranhas (upper) formations [3].

The formations are described by Rocha and Amaral (2006) [8] in Table 1.

\subsection{Topography}

The relief of the Rio do Peixe Basin is approximately flat. The altitude varies from $174 \mathrm{~m}$ to just over $330 \mathrm{~m}$ according to the map made using data from the V16.1 
global topography model developed by the Institute of Oceanography of the University of San Diego (Figure 5).

It can be observed that there is a gradual increase in the relief from the Pombal sub-basin to the Brejo das Freiras sub-basin. It is also notable that the basin is almost completely surrounded by hills which reach more than 600 meters.

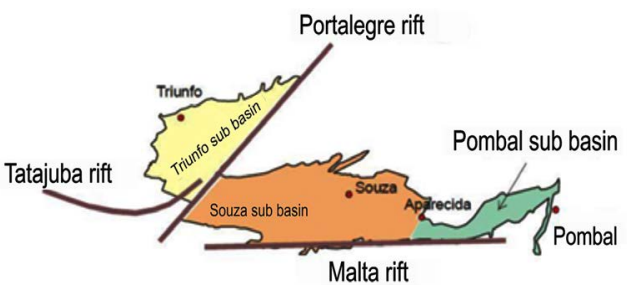

Figure 2. Structural subdivision of the Rio do Peixe Basin [7].

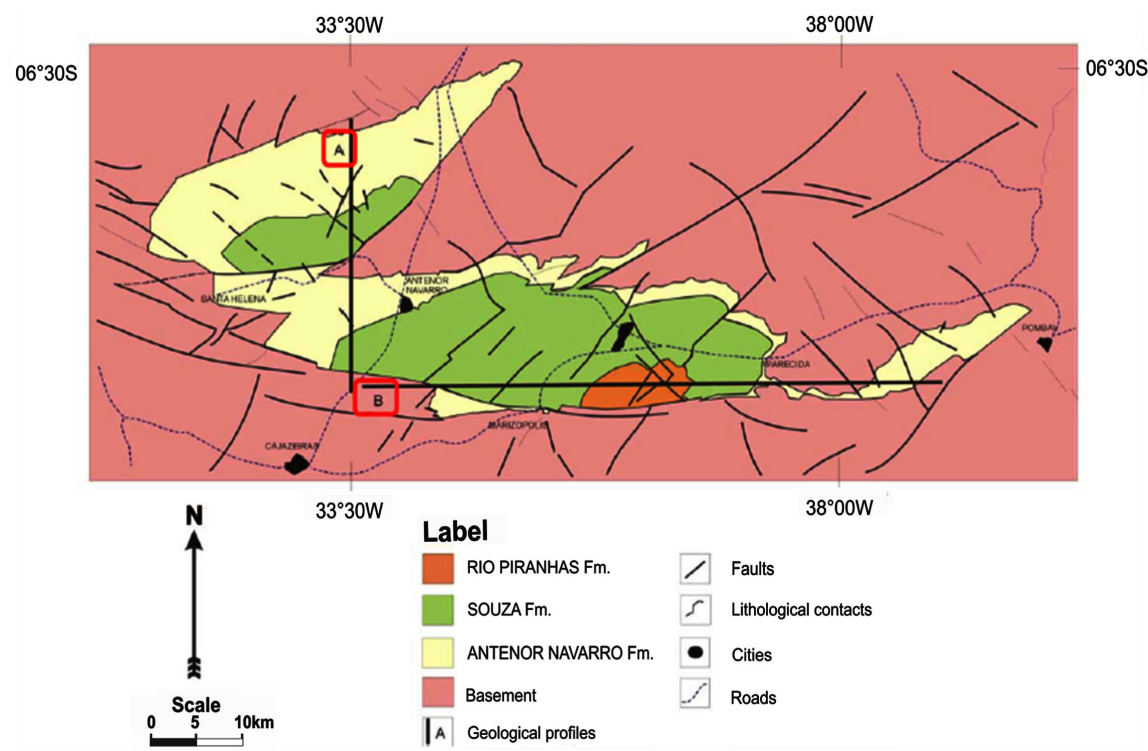

Figure 3. Geologic map of the Rio do Peixe Sedimentary Basin [3].
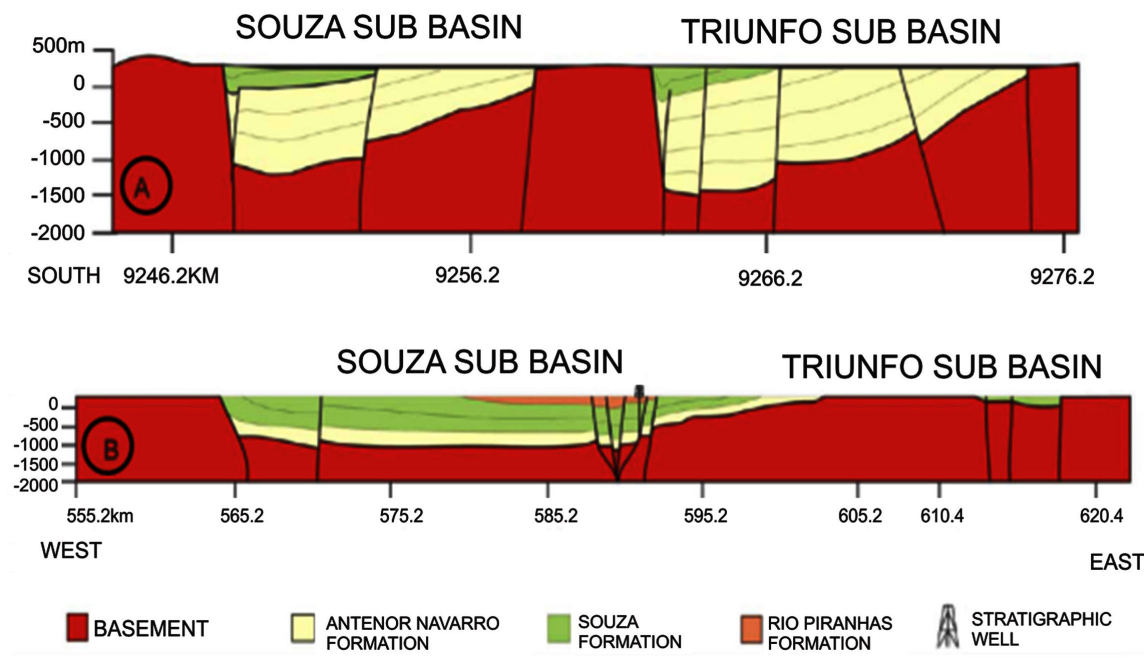

Figure 4. Geological sections of the Rio do Peixe Basin [3]. 


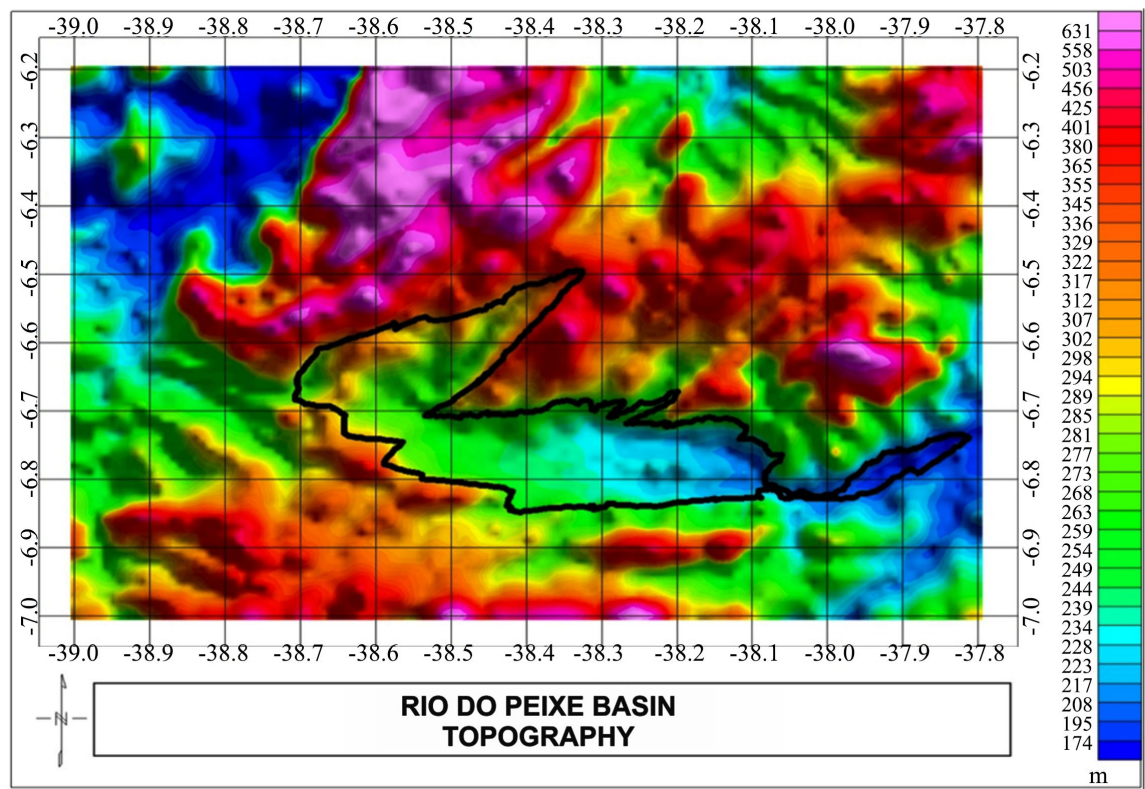

Figure 5. Topographic map of the Peixe River Basin.

Table 1. Geological formations of the Peixe River Basin [8].

\begin{tabular}{|c|c|}
\hline Formation & Geology \\
\hline & $\begin{array}{l}\text { It is composed of conglomeratic thick sandstones, containing levels of } \\
\text { conglomerates and medium to fine sandstones. In the Brejo das Freiras }\end{array}$ \\
\hline & Sub-basin, the Antenor Navarro Formation is formed by conglomeratic \\
\hline Antenor & sandstones, with ribbed cross stratification. In the Sousa Sub-basin, the formation \\
\hline \multirow[t]{5}{*}{ Navarro } & has the previously mentioned sandstones, being associated with banks of levels of \\
\hline & polymictic conglomerates on the northern border. In the Pombal sub-basin, it is \\
\hline & associated to the Malta shear zone, with the occurrence of a polymorphic \\
\hline & conglomerate composed of blocks that can reach up to $1.5 \mathrm{~m}$ in diameter/length. \\
\hline & $\begin{array}{l}\text { It is represented by the upper unit of the Rio do Peixe Group, occurrences are } \\
\text { restricted to the southern portion of the Sousa Sub-basin, where it has }\end{array}$ \\
\hline Rio & approximately 100 meters, and can reach up to 300 meters of thickness. Its \\
\hline \multirow[t]{6}{*}{ Piranhas } & composition is largely conglomeratic, feldspathic and lytic, poorly selected, light \\
\hline & gray to reddish brown, having intercalations of medium to fine sandstones and \\
\hline & siltstones. \\
\hline & It occupies about $70 \%$ of the area of the Sousa and Pombal sub-basins and $50 \%$ \\
\hline & of the Brejo das Freiras Sub-basin and has a maximum thickness of 800 meters in \\
\hline & the Sousa Sub-basin, being able to reach a little more in the Brejo das Freiras \\
\hline Formação & Sub-basin. One of the main exhibitions of the upper Sousa Formation is located \\
\hline \multirow[t]{4}{*}{ Sousa } & in the Pedregulho site where a sequence of siltstones, argillites, and fine, brownish \\
\hline & sandstones appear, presenting flat-parallel laminations. The lower part is well \\
\hline & represented in the locality of Passagem das Pedras where shales dominate the \\
\hline & formation. \\
\hline \multirow{3}{*}{$\begin{array}{l}\text { Cenozoic } \\
\text { Coverage }\end{array}$} & It is represented by the alluvial deposits along the extension of the main rivers, \\
\hline & such as the Piranhas and Peixe rivers and their main tributaries. It is composed of \\
\hline & sandy, conglomerate sediments as well as clayey portions. \\
\hline
\end{tabular}

\section{Magnetometric Method}

\subsection{Magnetic Anomalies}

The magnetometer is an instrument used to measure the intensity of the Earth's 
magnetic field. This intensity can vary according to the magnetization of rocks in the Earth's crust that generates a certain disagreement between the actual value of intensity and the theoretical value. This difference is called Magnetic Anomaly, it is the difference of the real and expected magnitude for a given location [9].

According to Lowrie (2007) [10], basically, the magnetometric method consists in obtaining the magnetic anomaly through the following steps:

1) Measurement of the Earth's magnetic field at predetermined points;

2) Correction of measurements for known changes;

3) Comparison of the resulting field value with the expected value at each measuring station. The expected field value anywhere is considered the international reference geomagnetic field (IGRF). The difference between the observed and expected values is called a magnetic anomaly.

According to Sordi (2008) [11], magnetometry measures small variations in the intensity of the Earth's magnetic field from rocks that have variable magnetism distributed in the Earth's crust above the Curie surface. One can calculate the magnetic field of an isolated surface, using the Equation (1):

$$
\mathrm{AF}=\mathrm{MF}-(\mathrm{EF}+\mathrm{GF})
$$

at where:

$$
\begin{aligned}
& \mathrm{AF}=\text { Anomalous magnetic field }(<1 \%) ; \\
& \mathrm{MF} \text { = Measured field; } \\
& \mathrm{EF} \text { = External magnetic field (Diurnal-External sources to the planet); } \\
& \mathrm{GF} \text { = Geomagnetic field-IGRF (99\%). }
\end{aligned}
$$

The magnetic susceptibility is presented by each rock in different intensities, being the sedimentary rocks with lower intensity, and the igneous and metamorphic ones with greater intensity. Thus, when magnetic anomalies are observed in environments covered by sediment deposition, they are generated by igneous and metamorphic rocks and/or intrusions. The most common causes of anomalies are dikes, sills, metamorphic or igneous foundations and bodies of magnetite ores [1].

\subsection{Horizontal and Vertical Derivatives}

Blakely (1995) [12] states that derivative filters are techniques where the Magnetic Anomaly undergoes a linear modification, through the derivation of the horizontal and vertical components of the magnetic field. The horizontal derivative in the Fourier domain is given by Equation (2).

$$
F\left[\frac{\mathrm{d}^{\prime \prime} T}{\mathrm{~d} x^{\prime \prime}}\right]=\left(i k_{x}\right)^{n} F[T] \text { and to } F\left[\frac{\mathrm{d}^{\prime \prime} T}{\mathrm{~d} y^{\prime \prime}}\right]=\left(i k_{y}\right)^{n} F[T]
$$

at where:

$k_{x}$ and $k_{y}$ are the wave numbers in the directions $x$ and $y$.

These filters change in functions of a linear surface in a derivative of order $\mathrm{n}$, with respect to $x$ and $y$.

The vertical derivative is obtained through the above equations and the Lap- 
lace Equation (3).

$$
\frac{\partial^{2} T}{\partial x^{2}}+\frac{\partial^{2} T}{\partial y^{2}}+\frac{\partial^{2} T}{\partial z^{2}}=0
$$

In frequency domain:

$$
\begin{gathered}
F\left(\frac{\partial^{2} T}{\partial x^{2}}\right)+F\left(\frac{\partial^{2} T}{\partial y^{2}}\right)+F\left(\frac{\partial^{2} T}{\partial z^{2}}\right)=0 \\
-\left(k_{x}\right)^{2} F(T)-\left(k_{y}\right)^{2} F(T)+F\left(\frac{\partial^{2} T}{\partial z^{2}}\right)=0 \\
F\left(\frac{\partial^{2} T}{\partial z^{2}}\right)=\left(k_{x}\right)^{2} F(T)+\left(k_{y}\right)^{2} F(T) \\
F\left(\frac{\partial^{2} T}{\partial z^{2}}\right)=\left(k_{z}\right)^{2} F(T)
\end{gathered}
$$

As the nth-order vertical gradient is equal to the Fourier transform of the potential times $\left(k_{z}\right)^{n}$, in a similar fashion, the vertical derivative of nth-order with wave number $k_{z}$ is obtained through Equation (4).

$$
F\left[\frac{\partial^{\prime \prime} T}{\partial z^{\prime \prime}}\right]=\left(k_{z}\right)^{n} F[T]
$$

at where:

$k_{z}=$ wave number in the $z$ direction.

\subsection{Analytical Signal}

According to Roest (1992) [13], the amplitude of the 3D analytical signal at ( $x, y)$ can be simply derived from the total magnetic field in three orthogonal gradients. The amplitude of the analytical signal can be placed at low altitudes where other techniques generally fail as in the case of reduction to the magnetic pole. The analytical signal is made by combining the vertical and horizontal gradients of the magnetic anomaly. The amplitude is given by Equation (5).

$$
\left|A_{(x, y)}\right|=\sqrt{\left(\frac{\partial T}{\partial x}\right)^{2}+\left(\frac{\partial T}{\partial y}\right)^{2}+\left(\frac{\partial T}{\partial z}\right)^{2}}
$$

at where:

$\left|A_{(x, y)}\right|=$ amplitude of the analytical signal in $(x, y)$;

$\left(\frac{\partial T}{\partial x}\right),\left(\frac{\partial T}{\partial y}\right)$ and $\left(\frac{\partial T}{\partial z}\right)=$ horizontal derivatives in $\mathrm{x}$ and $\mathrm{y}$ and vertical derivative in $Z$, respectively;

$T=$ magnetic anomaly.

The analytical signal is able to locate the edges of magnetic bodies, regardless of their geometry and the remaining magnetization. Therefore, it is a good locator of magnetic rocks. 


\subsection{Euler Deconvolution}

Euler Deconvolution was introduced by Thompson in 1982 to provide rapid analysis of large amounts of magnetic data. It is a technique widely used in the interpretation of magnetic data, since it allows estimating the average depth of sources or magnetic bodies [14].

This technique uses the Euler equation (Equation (6)) to enable estimation of the position, depth, and type of magnetic sources [15].

$$
x \frac{\partial T}{\partial x}+y \frac{\partial T}{\partial y}+z \frac{\partial T}{\partial z}=N T
$$

at where:

$$
\begin{aligned}
& x, y \text { and } z=\text { Cartesian coordinates; } \\
& T=\text { Magnetic field; } \\
& N=\text { degree of homogeneity. }
\end{aligned}
$$

The method can be used to estimate the location of a wide variety of geological structures such as faults, magnetic contacts, dikes, and sills. These structures are classified by a parameter denominated as a structural index, which is related to the nature of the anomaly and is, according to Barbosa and Silva [16], the measurement of the magnetic anomaly decay rate with the distance between the source and measurement point. Table 2 compares geological models with the structural index for magnetic data.

Ribeiro, Queiroz, and Santos (2015) [15] detail the structural index (I), where: $I=0$, it is used to identify geological contacts, which are regions where there are contact between layers of different rocks;

$I=1 / 2$, it is used to verify regions of fault, shear, and fracture in layers of rocks;

$I=1$, it is used to detect intrusive rocks, such as dikes (vertical intrusions) and sills (horizontal intrusions);

$I=2$, it is used to identify cylindrical shaped sources, which may be kimberlite chimneys, for instance;

$I=3$, it is used as a model to identify spherical sources, such as iron ore agglutinations.

For Thompson (1982) [14], the most suitable value for a structural index is one that presents a set of solutions with the lowest possible standard deviation. Therefore, the definition of the structural index depends strictly on the type of source on which the depth is estimated.

Table 2. Structural Index [17].

\begin{tabular}{cc}
\hline Index & Geometric shape of the anomalous source \\
\hline 0 & Geological Contacts \\
$1 / 2$ & Fault Regions \\
1.0 & Dikes and Sills \\
2.0 & Cylinder \\
3.0 & Sphere or dipole \\
\hline
\end{tabular}


For each structural index chosen, it is possible to estimate the geographic coordinates of the source that causes the anomaly by solving the Euler equation in a moving window measured at the point of $T_{i}(x, y, z)$ and with its derivatives, in an overdetermined system (Equation (7)).

$$
\left[\begin{array}{ccc}
\frac{\partial T_{1}}{\partial x} & \frac{\partial T_{1}}{\partial y} & \frac{\partial T_{1}}{\partial z} \\
\frac{\partial T_{2}}{\partial x} & \frac{\partial T_{2}}{\partial y} & \frac{\partial T_{2}}{\partial z} \\
\vdots & \vdots & \vdots
\end{array}\right]\left[\begin{array}{l}
x-x_{0} \\
y-y_{0} \\
z-z_{0}
\end{array}\right]=N\left[\begin{array}{c}
T_{1} \\
T_{2} \\
\vdots
\end{array}\right]
$$

After selecting the structural index, the dimensions of the movable window must be determined. This window crosses the mesh, producing the set of solutions. The location of the sources is considered optimal when there is little scattering of the solutions, so different windows can generate solutions in similar positions (Figure 6) [18].

To achieve more reliable results, the size of the window must be sufficient for the inclusion of the anomaly. The noise can distort the understanding of the magnetic sources, so it is necessary data filtering before using them [19].

\section{Processing and Results}

We used aerial magnetometry data from the Iguatu Project, which were collected through the proton magnetometer GEOMETRICS model G-803, with the sensor mounted at Islander and Bandeirante aircraft. The profiles were flown with 150 $\mathrm{m}$ height, N45W direction, and $1000 \mathrm{~m}$ spacing (Figure 7).

Through the collected data, maps of Magnetic Anomaly, Horizontal and Vertical Derivatives and Analytical Signal were made. Interpolation was done using the minimal curvature method with 250-meter cells through Geosoft's Oasis Montaj software. The minimal curvature method generates a new grid of points by successively applying the regression model on the grid of iterative, so that with each passage it is possible to achieve a better level of smoothing.

In the possession of the raw data collected by the magnetometer, the IGRF values and the correction of the diurnal variation were subtracted, in addition to leveling operations. The result reflects the crust magnetic field, being called magnetic anomaly map (Figure 8).

The comparison of the magnetic anomaly map (Figure 8) with the geological maps (Figure 2 and Figure 3 ) shows a strong magnetic anomaly in the southern region of the basin associated to the Malta Fault, which horizontally cuts the Triumph Sub-Basin. Another strong magnetic anomaly occurred in the central part of the map in the southwest to northeast direction associated with a fault that begins in the outskirts of the Sousa City.

The horizontal and vertical derivatives were calculated according to Equations (2) and (4), generating the horizontal derivative maps in the $\mathrm{x}$-direction (Figure 
9), horizontal derivative in the y-direction (Figure 10) and vertical derivative (Figure 11).

The maps of derivatives allow the identification of the main regional faults. The Tatajuba fault was best evidenced in the horizontal derivative map in the $\mathrm{x}$-direction at its end. The Portalegre fault has a better presentation on the horizontal derivative map in the $\mathrm{x}$-direction and on the vertical derivative map.

Finally, the Malta fault, which had greater contrast in all maps, becoming very evident in the vertical derivative map. In addition, it is possible to identify in all maps the presence of minor and peripheral faults of the basin, as shown in Figure 3.

It was possible to calculate the analytical signal of the Rio do Peixe Basin using the calculated values of the horizontal and vertical derivatives in Equation (5) (Figure 12).

The analysis of the analytical signal map shows the basin has the lowest regional values of analytical signal, since these are associated to the sediments which have very low magnetic susceptibility. The highest values are associated with the main failures in the region. The three main faults (Tatajuba Fault, Portoalegre Fault, and Malta Fault) were very well evidenced in the map.

The Malta fault is very well explained on the map, and its position can be clearly noticed, in which it completely crosses south of the Sousa sub-basin, which is confirmed in the map of Figure 2.

It is possible to notice the Portalegre Fault crossing the eastern boundary of the Triunfo sub-basin, as well as the Tatajuba Fault and some points of the basement neighboring the basin region, all with high values of analytical signal.

Through the values of the horizontal and vertical derivatives in Equation (7), it is possible to calculate the Euler deconvolution in the region of the Peixe River basin. It can reveal the location in the plane and the depth of the main regional magnetic bodies.

The structural index $1 / 2$ was used. According to Table 1 , it is used to identify regional faults. The result of the Euler deconvolution is shown in Figure 13.

Lastly, the analysis of the Euler deconvolution map allows to identify the main regional faults and to estimate a depth of almost $1400 \mathrm{~m}$, which is compatible with the seismic transects A and B (Figure 4).

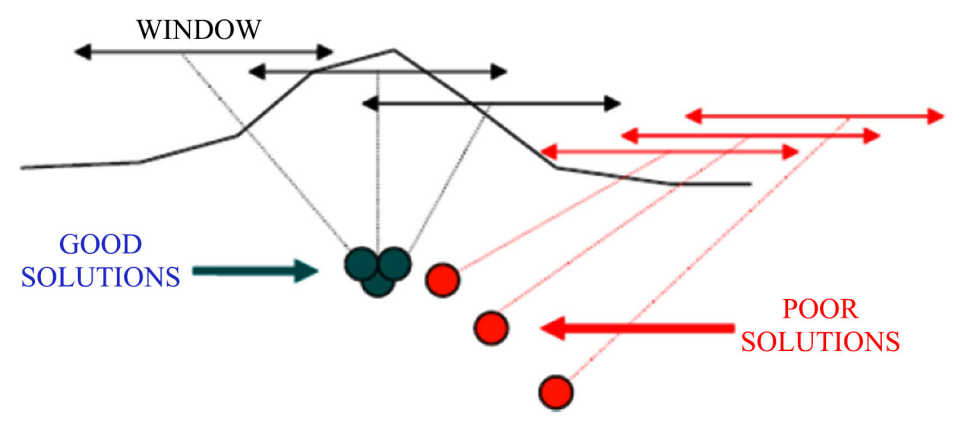

Figure 6. Quality of Euler Deconvolution solutions [18]. 


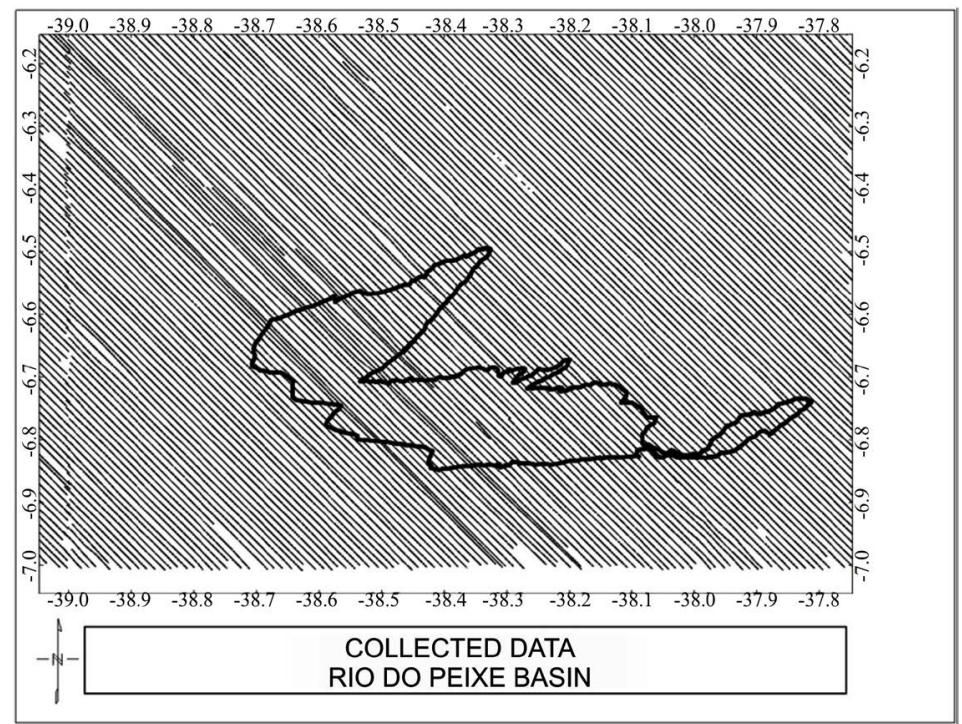

Figure 7. Collected data in the Iguatu Project.

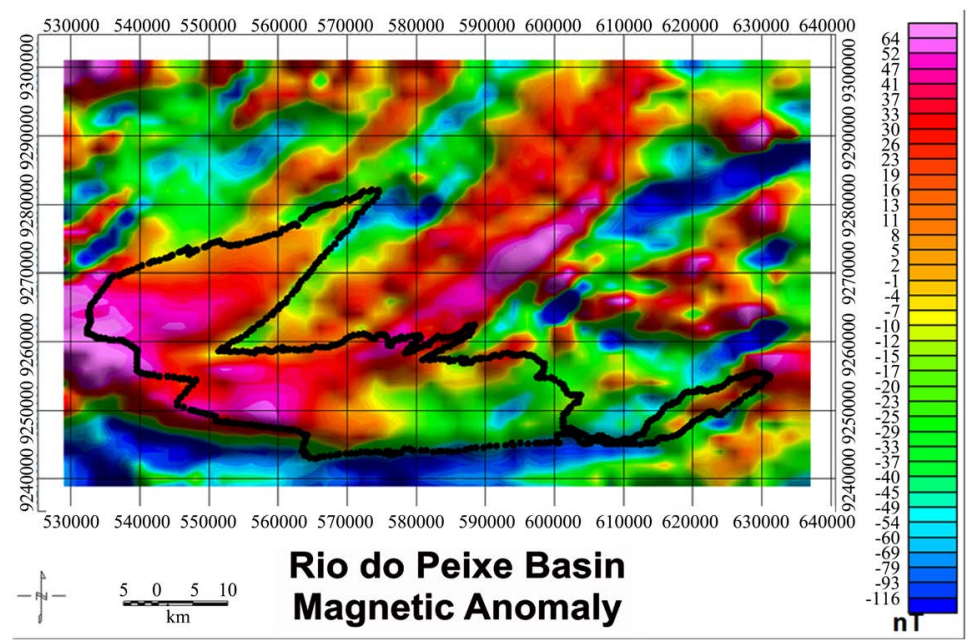

Figure 8. Map of Magnetic Anomaly.

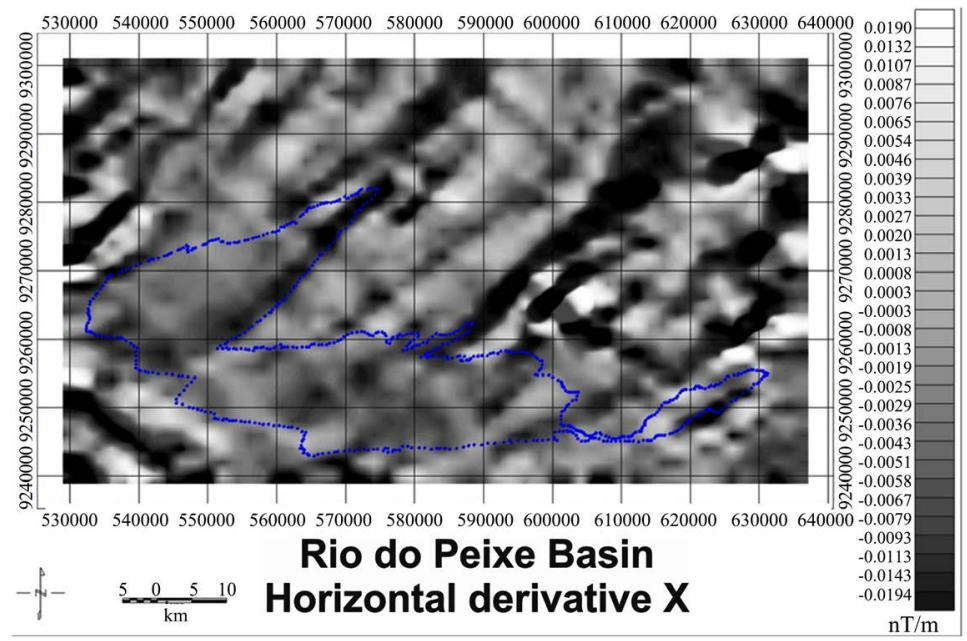

Figure 9. Horizontal derivative in the $\mathrm{X}$ direction. 


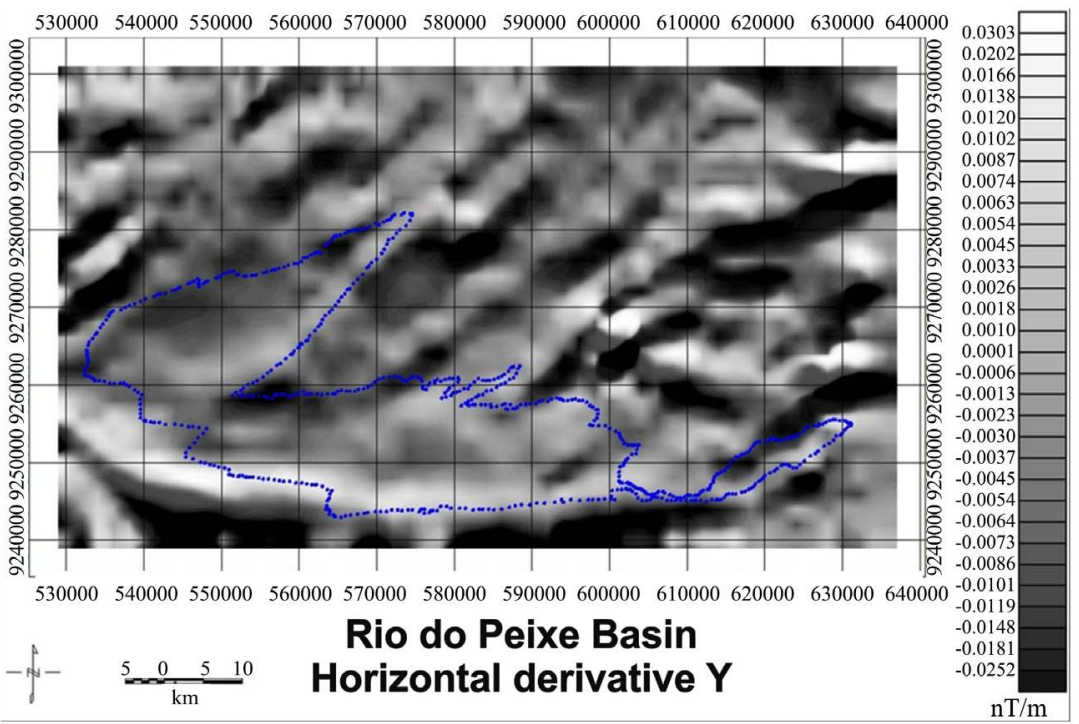

Figure 10. Horizontal derivative in the $\mathrm{Y}$ direction.

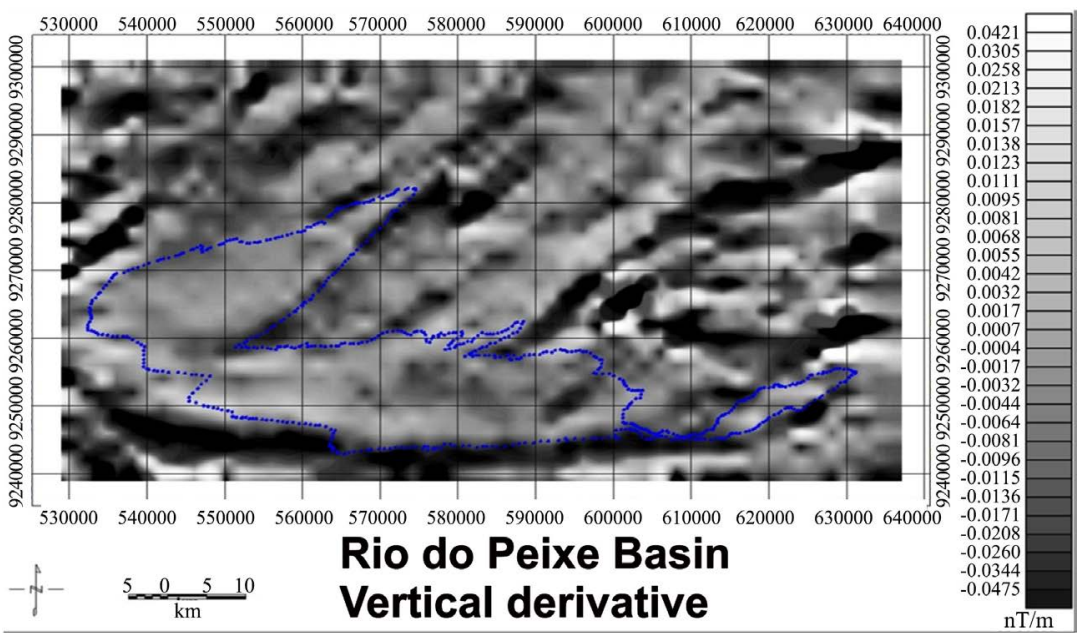

Figure 11. Vertical derivative in the $\mathrm{Z}$ direction.

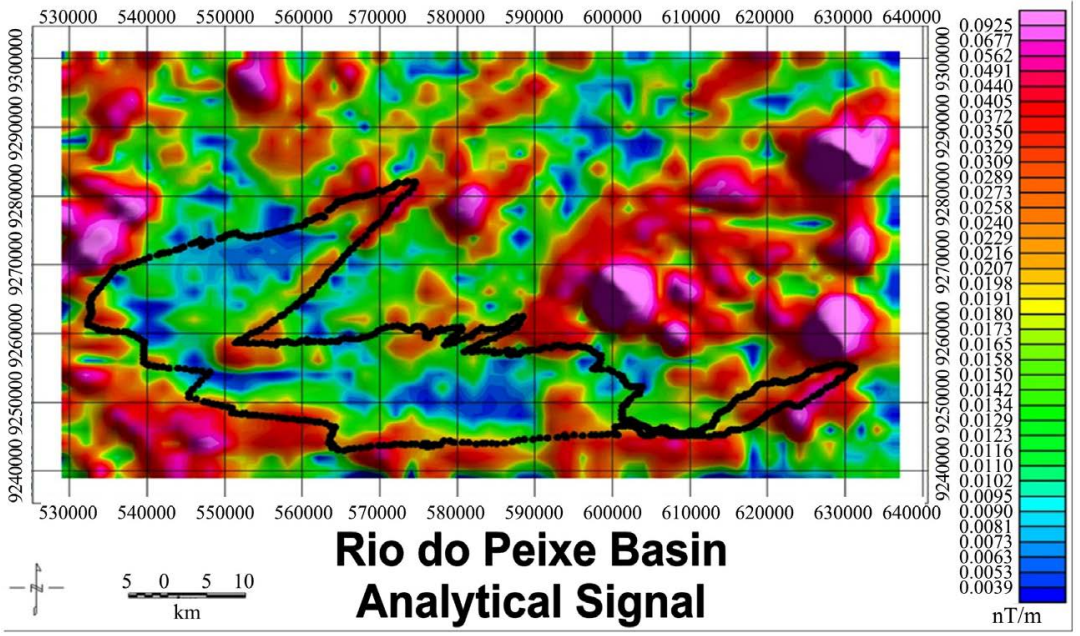

Figure 12. Analytical Signal Map. 


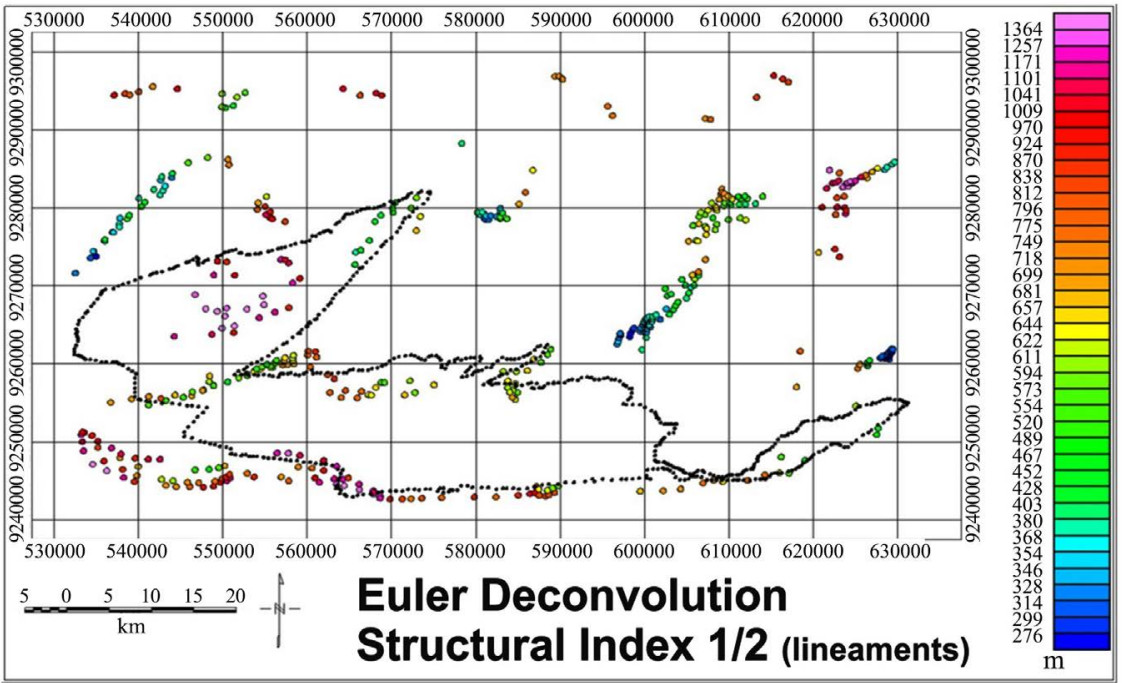

Figure 13. Euler Deconvolution Map with Structural Index I = 1/2.

\section{Conclusions}

Oil prospecting is an activity that spends a lot of financial resources, especially in the oil demand phase. Costly methods commonly used as seismic and magnetotelluric are best applied when using other techniques to improve efficiency and effectiveness, such as the magnetometric method. In this sense, the results of this work are useful because they can help lead new researches in the region.

The study area was the Rio do Peixe basin with a proven petroleum system which was the target of block auctions made by the ANP for petroleum exploration. In this context, this work uses the magnetometric method to study the basin to later generate the maps that were compared with the seismic data provided by the ANP. Magnetic anomaly, horizontal and vertical derivatives, analytical signal and Euler Deconvolution maps were made.

It was observed that the maps obtained in the processing provide in a similar way what is explained in the seismic information of the ANP survey. It guarantees reliability in the products made in this work.

The evidenced faults in the geological map were identified in the magnetometric maps, mainly the three main ones, Tatajuba, Portalegre and Malta faults. The depth of the basin was also another result that was similar to the seismic surveys of the region, in which the maximum depth of the basin turns around 1400 meters. Since the estimated depth in the processing of this work is around 1364 meters.

It is recommended for future work the application of a joint modeling of seismic data and magnetic data linked to data from wells already drilled in the region that can give rise to a more realistic model of sediment depth.

\section{Acknowledgements}

The authors would like to express their thanks to the Engineering Production Coordinator André A. Manzella from Faculdade Salesiana Maria Auxiliadora for 
trusting and supporting the work.

\section{Conflicts of Interest}

The authors declare no conflicts of interest regarding the publication of this paper.

\section{References}

[1] Kearey, P., Brooks, M. and Hill, I. (2002) An Introduction to Geophysical Exploration. Blackwell Science Ltd., Hoboken, NJ.

[2] Thomas, J.E. (2001) Fundamentos de Engenharia de Petróleo. Interciência, Rio de Janeiro.

[3] ANP (2007) Nona Rodada de Licitações da Bacia do Rio do Peixe. Brasil Round 9.

[4] Córdoba, V.C., Antunes, A.F., De Sá Jardim, E.F., Silva, A.N., Sousa, D.C. and Lins, F.A.P.L. (2008) Analise estratigráfica e estrutural da Bacia do Rio do Peixe, Nordeste do Brasil: Integração de dados a partir do levantamento sísmico pioneiro 0295_rio_do_peixe_2d. Boletim de Geociencias da Petrobras, 16, 53-68.

[5] CPRM. (2007) Hidrogeologia da Bacia Sedimentar do Rio do Peixe. Meta C, Caracterização Hidrogeológica de Aquíferos. Ministério de Minas e Energia.

[6] Silva, A.N. (2009) Arquitetura, Litofáceis e Evolução Tectono-Estratigráfica da Bacia do Rio do Peixe. Dissertação de Mestrado. Universidade Federal do Rio Grande do Norte, Natal, Rio Grande do Norte, Brazil.

[7] Fernandes, I.Y., Muniz, M.Y., Costa Júnior, J.N.R. (2017) Avaliação Do Potencial Gerador Da Formação Sousa, Bacia Do Rio Do Peixe, Utilizando Dados De Pirólise Rock-Eval E Carbono Orgânico Total. X Simpósio sul Brasileiro de Geologia, Curitiba. http://ssbg2017anais.siteoficial.ws/apresentacoes/102.pdf

[8] Rocha, D. and Amaral, C. (2006) Comportamento das Bacias Sedimentares da Região Semi-Árida do Nordeste Brasileiro. Fundo Setorial de Recursos Hídricos.

[9] Cordani, R. (2008) Desenvolvimento de metodologia para aplicar técnicas do paleomagnetismo em anomalias magnetométricas em crosta continental: Aplicação a anomalias brasileiras. Revista Brasileira de Geofísica, 27, 110p.

https://doi.org/10.1590/S0102-261X2009000200015

[10] Lowrie, W. (2007) Fundamentals of Geophysics. Second Edition, Cambridge University Press, Cambridge. https://doi.org/10.1017/CBO9780511807107

[11] Sordi, D. (2008) Aerogeofísica-Magnetometria e Gamaespectotria. Dissertação de Mestrado, University of Brasília, Brasília.

[12] Blakely, R.J. (1995) Potential Theory in Gravity and Magnetic Applications. Cambridge University, Cambridge. https://doi.org/10.1017/CBO9780511549816

[13] Roest, W.R., Verhoef, J. and Pilkington, M. (1992) Magnetic Interpretation Using the 3-D Analytic Signal. Geophysics, 57, 116. https://doi.org/10.1190/1.1443174

[14] Thompson, D.T. (1982) EULDPH: A New Technique for Making Computer-Assisted Depth Estimates from Magnetic Data. Geophysics, 47, 31-37. https://doi.org/10.1190/1.1441278

[15] Ribeiro, J.D., Queiroz, I.M.S. and Santos, H.S. (2015) Depth Basement Estimate of the Alto Xingu Sub-Basin, Brazil. International Journal of Engineering Sciences and Emerging Technologies, 7, 725-736.

[16] Barbosa, V.C.F. and Silva, J.B.C. (2005) Deconvolução de Euler: Passado, Presente e Futuro-Um tutorial. Revista Brasileira de Geofísica, 23, 243-250. 
https://doi.org/10.1590/S0102-261X2005000300004

[17] Correia, M.G. (2008) Estimativa de Profundidades Magnéticas na Província Mineral de Carajás, Brasil. Dissertação de Mestrado, Universidade de Aveiro, Aveiro, Portugal.

[18] Silva, J.R.S. (2007) Estudo do Levantamento Aerogeofísico do Estado do Rio de Janeiro na Região dos Lagos. Observatório Nacional, Rio de Janeiro.

[19] Durrheim R.J. and Cooper G.J.R. (1998) EULDEP: A Program for the Euler Deconvolution of Magnetic and Gravity Data. Computers and Geosciences, 24, 545-550. https://doi.org/10.1016/S0098-3004(98)00022-3 